\title{
A Lapita presence on Arop/Long Island, Vitiaz Strait, Papua New Guinea?
}

\author{
Dylan Gaffney, Glenn R. Summerhayes and Mary Mennis
}

\begin{abstract}
This chapter investigates how Lapita communities used the Vitiaz Strait as a conduit for migration and exchange. We report provisional archaeological work on Arop/Long Island in the Vitiaz Strait of Papua New Guinea, providing insight into occupation prior to the c. 1660 AD eruption. This includes the finding of a potsherd overlapping in form and technology with Lapita plainware from the Siassi Islands. This sherd is tempered with sand probably deriving from Schouten Arc geology of south-west New Britain. Type X and Madang-style pottery is also present. Obsidian stone tools from surface collections all derive from the Kutau-Bao source in West New Britain and these were supplemented by local low-quality volcanic raw materials. We posit that these tentative finds are suggestive of Lapita occupation on the island, or exchange with Lapita communities around New Britain.
\end{abstract}

\section{Introduction}

We have a limited understanding of the movement of Lapita peoples and their material culture into the Vitiaz Strait of north-east New Guinea. However, the Strait and its string of islands bridging the Bismarck Archipelago and the New Guinea mainland could have been an important area facilitating the movement of Austronesian communities into the Pacific, or during subsequent movements and interactions between the Bismarcks and the mainland. The distribution of sites bearing Lapita pottery in the Vitiaz Strait has previously been restricted to the Siassi Islands, south-west of New Britain (Lilley 2002: Figure 1). Here we describe artefacts collected from provisional surface survey on Arop/Long Island over $100 \mathrm{~km}$ to the west. One of these finds is a potsherd, which overlaps in form and technology with Lapita plainware described in the Siassi group and further east on New Britain. Obsidian was also collected, which demonstrates exchange links with the Bismarck Archipelago. Although these findsparticularly the ceramics - are extremely limited and are not from excavated contexts, they are unquestionably suggestive and can be tentatively incorporated into broader scenarios of Lapita settlement, population movement and interaction. 


\section{Lapita in the Vitiaz Strait}

There is consensus among most archaeologists that the appearance of Lapita pottery in the Bismarck Archipelago by 3350 years ago marks the arrival of Austronesian-speaking peoples (hereafter Austronesians) into Near Oceania (Kirch 2000; Summerhayes 2007a, 2007b). Despite this, their origins and route into the Pacific prior to these dates are highly debated. One school of thought suggests a pulse-pause expansion out of Taiwan, through Island Southeast Asia (ISEA) and along the north coast of New Guinea (Bellwood 1998; Bellwood and Dizon 2008; Hung 2008). Others have posited a different route, through ISEA and into Micronesia before entering the Bismarcks (Bellwood 2011; Carson et al. 2013). Others again argue that Lapita is a cultural phenomenon deriving from the long-term interactions between numerous ISEA and Melanesian communities prior to 3350 years ago (Specht et al. 2014; Terrell 2004). However, once in the Bismarcks, these Austronesian communities moved with high mobility around the archipelago (Summerhayes 2000), into Remote Oceania by 3000 years ago (Kirch 2000; Sheppard et al. 2015), onto the south Papuan coast by 2900 years ago (McNiven et al. 2011; Negishi and Ono 2009; Skelly et al. 2014), and perhaps back onto the north New Guinea coast (Lilley 1999, 2000).

Many of these narratives are supported (or challenged) by historical linguistics, biological anthropology and DNA studies (e.g. Blust 2009; Chang et al. 2015; Oppenheimer 2004; Skoglund et al. 2016; Valentin et al. 2016). It has previously been argued, based primarily on linguistic evidence (see Ross 1988), that the scattered Austronesian speakers on the islands of the Vitiaz Strait and off the north coast of New Guinea represent a western back-migration from communities based west of the Willaumez Peninsula in New Britain, sometime between 2000 and 500 years ago (Lilley 1999:28). More recent linguistic analyses using phylogenetics (e.g. Gray et al. 2009; Greenhill et al. 2010) suggest that the splitting of the North New Guinea Austronesian languages occurred earlier, perhaps between 3500-2500 years ago, although the analytical methods are still being refined (Greenhill pers. comm.; Ross pers. comm.). Austronesian loan words may also be present in Papuan languages along the north-east coast that hint at earlier eastward movements (Ross 1988:21). This is contrary to Terrell and Welsch (1997) and Pétrequin and Pétrequin (1998) who suggest that north coast Austronesian communities derive from Post-Lapita movements from the west, closer to ISEA, on the basis that north coast red-slipped pottery traditions, dating to about 1200 years ago, resemble plainware Lapita rather than the Post-Lapita ceramics in the Vitiaz Strait. However, the recent publication of a red-slipped sherd, securely bracketed to about 3212-2766 cal. BP from the Highlands site of Wañelek (JAO), may be evidence for an earlier establishment of potters along the north-east coast of the mainland (Gaffney et al. 2015). It is entirely possible, then, that there was an initial movement of Austronesians eastward along the north coast, and one or more Austronesian movements westward at a later stage.

Despite this, the archaeological evidence is still scarce, especially for Lapita-age occupation along the north-east coastline of New Guinea, along which Austronesian communities may have moved eastwards during initial colonisation; westwards in a subsequent movement out of the Bismarcks; or both. Only a small number $(\mathrm{n}=291)$ of Lapita potsherds have been excavated around north-east New Guinea, at the KLK site on Tuam Island in the Siassi group (Lilley 2002). These small coral islands are located almost equidistant from New Britain and New Guinea, separated from the former by the Dampier Strait and the latter by the Vitiaz Strait. The KLK finds, an assortment of very fragmentary rims and incised and dentate body sherds, date to 3612-2752 cal. BP (95.4 per cent probability using Marine13 calibration for shell (Reimer et al. 2013)). The earliest occupation, however, probably occurs at about $3150 \mathrm{cal}$. BP, based on stratigraphic evidence and overlapping radiocarbon distributions (Lilley 2002). This does not then represent the earliest Austronesian colonising period in the Pacific, but it is the earliest current evidence for human occupation of the Vitiaz Strait. 
The presence of Lapita pottery in the Siassi Islands is of no surprise, as it is also found just to the east on both the north and south coasts of New Britain, dating to 3200 years ago. In the Arawe Islands, located on south-west New Britain, Early Lapita pottery was found at a number of sites including Makekur (Adwe Island), Apalo (Kumbun Island) and Paligmete (Pililo Island), with later Lapita pottery found at all these sites and new ones such as Amalut on the mainland. Along the north coast of New Britain, Lapita pottery is recorded in the Kove area (Lilley 1991) and the Willaumez Peninsula (Specht and Torrence 2007a, 2007b).

The last traces of Lapita ceramics disappeared from the Vitiaz Strait by 2700 years ago (Lilley 2004), and the western tip of New Britain by 2300 years ago (Summerhayes 2000:27). Following Lapita occupation in the Strait, there is a ceramic hiatus until Type Y pottery appears, 1700 years ago (Lilley 2002; formerly included under the 'Lapita-style group' by Lilley 1986, Type $\mathrm{Y}$ is now seen as a distinct ceramic group on the basis of stratigraphy and peculiarities in technical attributes). This Post-Lapita tradition is, so far, found only at the KLK site on Tuam and it is not until the emergence of Type X, dated to around 1000 years ago (Lilley and Specht 2007), that sporadic interactions between New Britain and New Guinea, through the Vitiaz Strait, have been archaeologically visible. Type $\mathrm{X}$, which is posited to originate from the east Huon Peninsula, has been excavated from a number of sites on mainland New Guinea, in the Vitiaz Strait (Siassi Islands and Long Island), and around New Britain (Egloff and Specht 1982; Lilley 1988b). However, evidence for intensive, specialised trade configurations linking the western tip of New Britain with New Guinea, like those observed ethnographically (see Harding 1967), probably only arose in the last 300 years (Lilley 2004:91). These more recent trade networks are associated with distinct potting traditions based on mainland New Guinea. Recent pottery from Sio on the Huon Peninsula and Madang in Astrolabe Bay is found throughout sites on the north-east coast, in the Vitiaz Strait and in West New Britain, suggesting complex, overlapping trade spheres that facilitated the movement of material culture through distinct social fields (Lilley 1988a, 2007).

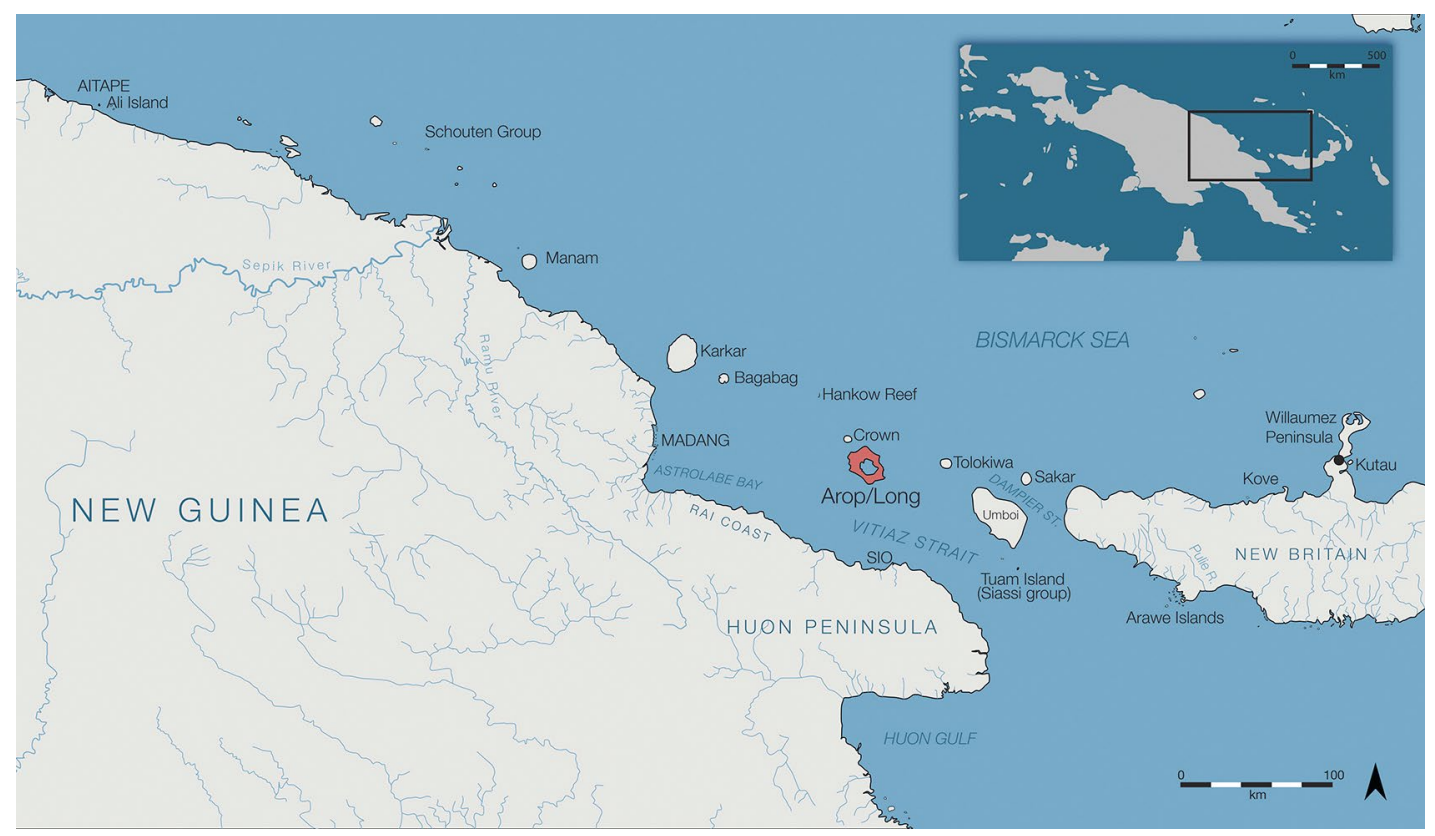

Figure 6.1. The north-east New Guinea area with places mentioned in the text and the study area, Arop/Long Island, highlighted.

Source: Illustration by authors. 


\section{Previous research on Arop/Long Island}

The focus here is Arop/Long Island, one in a chain of island volcanoes in the Bismarck Volcanic Arc stretching from the Schouten Group off the Sepik north coast to New Britain. Arop/Long lies over $100 \mathrm{~km}$ north-west of the Lapita site on Tuam, and about $50 \mathrm{~km}$ north of the mainland. The centre of the island is characterised by a large caldera lake, a volcanic crater produced by the last major eruption c. 290 BP (Blong 1982; Haberle 1998). This eruption, which would have been equivalent to Krakatoa on the Volcanic Explosivity Index (Smithsonian Institution, Global Volcanism Program), saw a massive depopulation of all macrobiota, including any humans who did not flee (Thornton 2001). Oral traditions from the north-east coast tell of gardens and houses being ruined by the resulting ashfall and a dramatic time of darkness (Mennis 2006a). As a result, many of the current populations derive from Tolokiwa Island, the Siassi group, or Sio on the mainland, and represent a recent repopulation of the island (Moeder 1972).

In $1700 \mathrm{AD}$ when Dampier sailed past the island, the eruption had already occurred, and the island was recovering with flourishing grasslands and woodlands. In Lapita times, however, the island may have been complete, with peaks much higher than today (Johnson 2013). In ethnographic and oral history accounts, the Arop/Long Islanders featured in complex trade and exchange networks, being visited by long-distance traders from the Siassi Islands and Astrolabe Bay and themselves sailing to the Huon Peninsula to exchange dog-teeth necklaces and shell ornaments (Mennis 2006a:54). The nature of settlement and trade relationships on Arop/ Long during Lapita times are not known.

Limited archaeological work has been undertaken on Arop/Long. The first archaeologists to visit the island were Egloff and Specht in 1973, spurred on by finds in 1969, 1970 and 1972 by historians, geographers and geologists either looking at the effects of recent eruptions or conducting social mapping (Egloff and Specht 1982). Specht et al. (1982) provides a history of research in the introduction to their Long Island monograph. In short, five archaeological sites were located on the island (Papua New Guinea site codes: JAB, JCB, JCC, JCT and JCW; see Figure 6.2).

On the eastern coast of the island at Kairu, JCT was found by botanist Womersley in the 1960s, but was not visited by either Egloff or Specht. The second site at Poin Bare, JAB, was recorded by geologist Wood in 1970 and collections were made by geographer Ian Hughes in 1972, who also recorded two more sites: JCB, north of Biliau, and JCC at Bara on the south coast. The JCW site was located north of Poin Bare by geologists Blong, McKee and Pain in 1976.

Only JAB, JCB and JCC were visited by Egloff and Specht in 1973. All of these sites are coastal and particularly important is Egloff and Specht's statement that no archaeological surveys were conducted in the island's interior where they acknowledge that earlier sites (earlier than the last eruptive phase) may be found eroding from channels cutting through the pyroclastic mantle (Egloff and Specht 1982:429).

Egloff and Specht (1982:430) identified early occupation at about 1100-1000 years ago, and major occupation between 550-350 years ago, based on terrestrial radiocarbon determinations. The excavators designated four ceramic style groups and associated the earliest dates with 'Stylegroup IV', which are consistent in rim form with pre-colonial Madang forms. Later occupation is associated with style groups I and II, which are consistent with Madang and Type X rim forms. However, none of their groups are stylistically diagnostic of Lapita pots and the earliest radiometric evidence for human occupation stands at only c. 1000 years ago. 


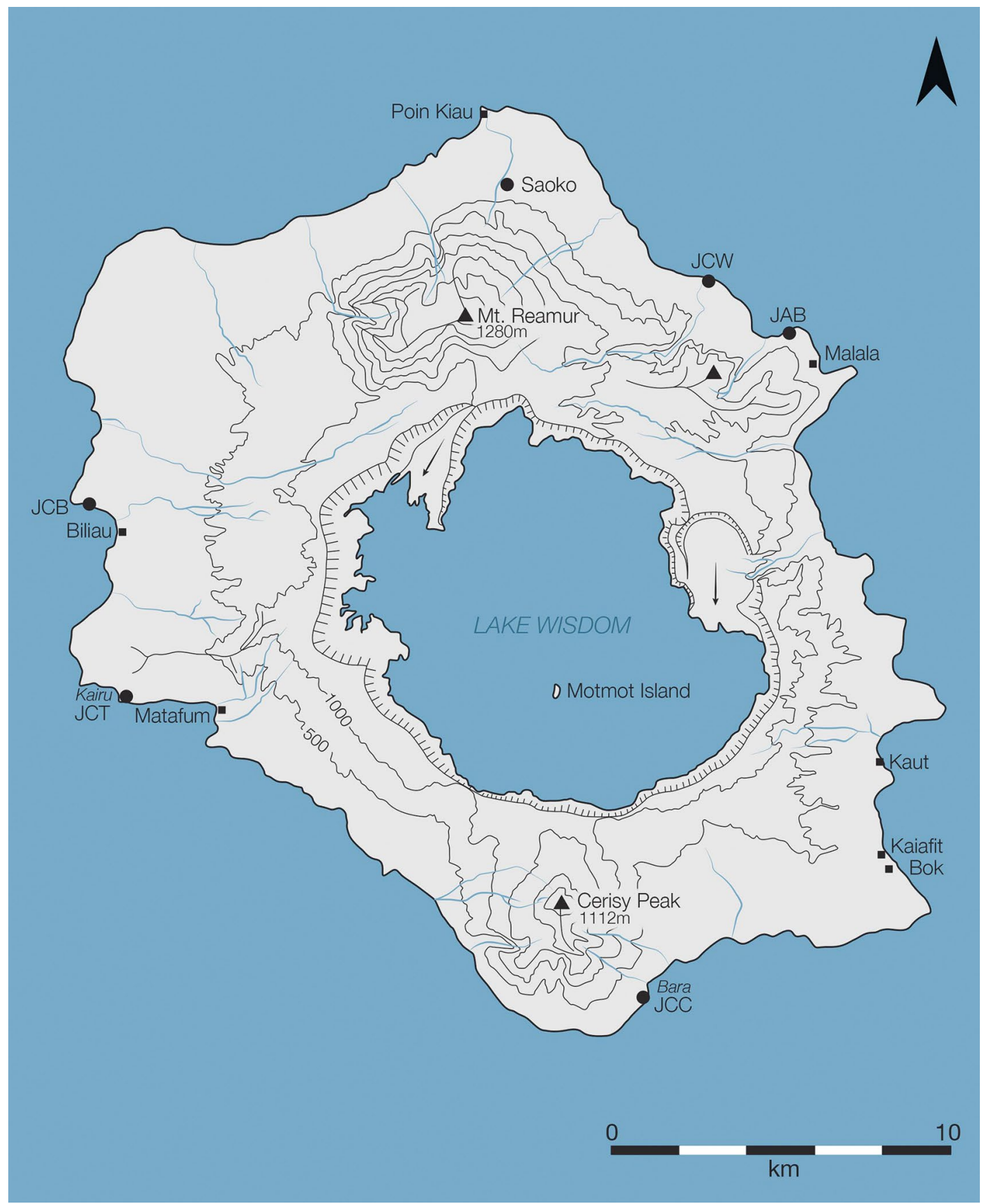

Figure 6.2. Arop/Long Island, showing archaeological sites and major settlements.

Source: Adapted from Johnson et al. 1972.

\section{Recent surface survey}

In June 2014 one of the authors (Mary Mennis) completed a non-systematic surface survey of artefacts around Arop/Long Island as part of a larger philanthropic and academic venture with Sir Peter Barter, former Governor of Madang Province, and three geologists—Russell Blong, Stewart Fallon and Chris McKee-who were reinvestigating the most recent volcanic eruption. The aim of the surface survey was to collect archaeological material for preliminary inspection and renewed site prospecting purposes. 


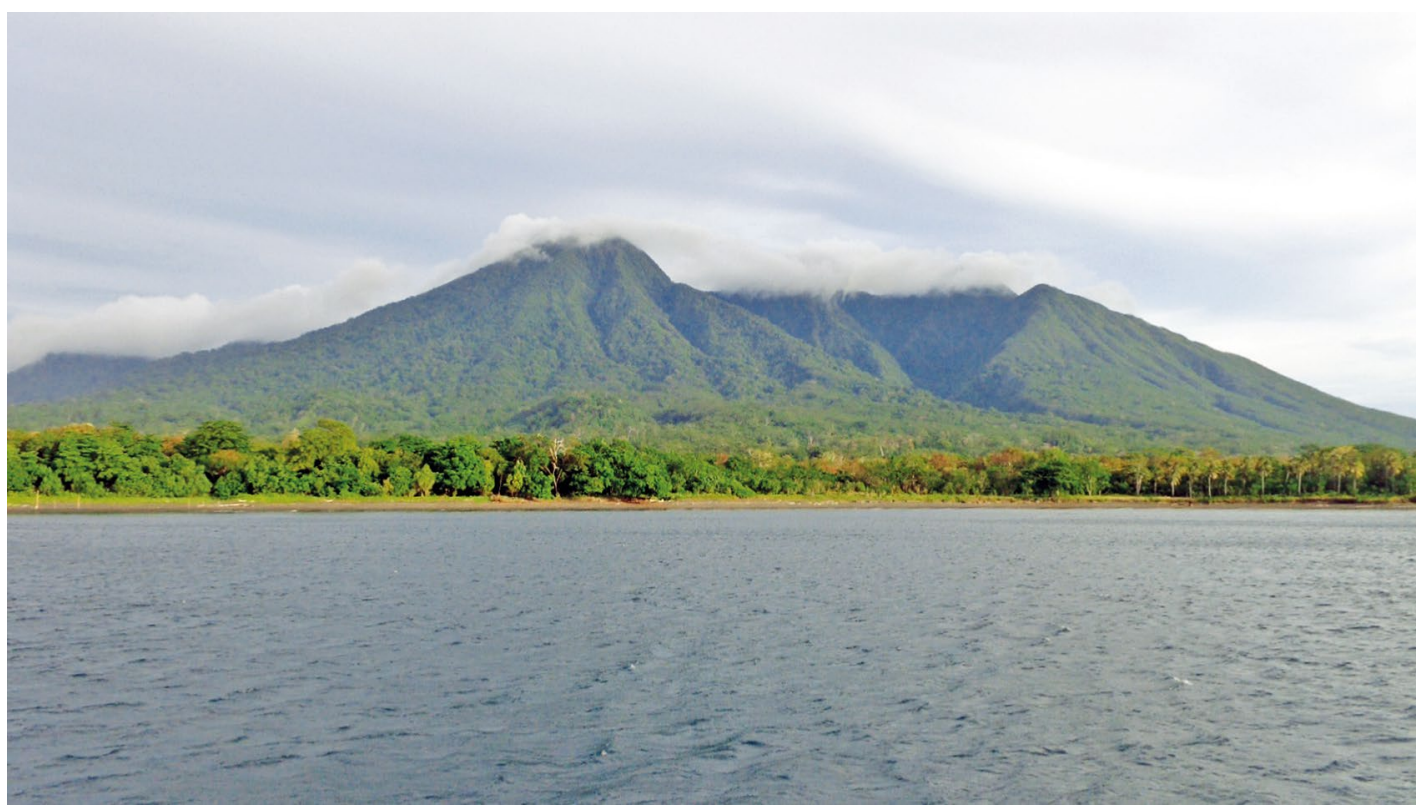

Figure 6.3. A view towards Poin Kiau and Mt Reaumur, Arop/Long Island.

Source: Mennis 2014.

Table 6.1. Catalogue of Arop/Long Island surface collections compiled by Mennis, 2014.

\begin{tabular}{|c|c|c|c|c|}
\hline Lab \# & Provenance & Artefact class & Description & Wt (g) \\
\hline LI-1 & Saoko village & pottery & rim sherd & 37.15 \\
\hline LI-2 & Matafum & pottery & rim sherd & 9.7 \\
\hline LI-3 & Saoko village & pottery & rim sherd & 19.75 \\
\hline LL-4 & Matafum & pottery & decorated sherd & 7.28 \\
\hline LI-5 & Matafum & pottery & plain body sherd & 2.25 \\
\hline LI-6 & Saoko village & obsidian & retouched flake & 1.98 \\
\hline LI-7 & Saoko village & obsidian & retouched flake & 3.00 \\
\hline LI-8 & Saoko village & obsidian & flake with usewear & 0.51 \\
\hline LI-9 & Poin Kiau & obsidian & core & 3.19 \\
\hline LI-10 & \begin{tabular}{|l|} 
Poin Kiau \\
\end{tabular} & stone & flake no usewear & 6.09 \\
\hline LL-11 & \begin{tabular}{|l|} 
Matafum \\
\end{tabular} & stone & angular fragment & 6.83 \\
\hline LLI-12 & \begin{tabular}{|l|} 
Matafum \\
\end{tabular} & stone & flake no usewear & 4.95 \\
\hline LL-13 & \begin{tabular}{|l|} 
Matafum \\
\end{tabular} & stone & flake no usewear & 3.73 \\
\hline LI-14 & Matafum & stone & flake no usewear & 5.69 \\
\hline LI-15 & Matafum & stone & flake no usewear & 12.06 \\
\hline LLI-16 & Matafum & stone & core & 14.33 \\
\hline LL-17 & Matafum & stone & core & 5.06 \\
\hline LI-18 & \begin{tabular}{|l|} 
Matafum \\
\end{tabular} & stone & core & 14.07 \\
\hline ㄴ-19 & Matafum & stone & оге & 3.12 \\
\hline LL-20 & Matafum & stone & core & 6.89 \\
\hline 니-21 & Matafum & stone & flake no usewear & 5.50 \\
\hline ㄴ-22 & Matafum & stone & flake no usewear & 8.82 \\
\hline LI-23 & Matafum & stone & core & 13.64 \\
\hline LI-24 & Matafum & stone & core & 179.37 \\
\hline
\end{tabular}

Source: Authors' summary data. 
A pre-colonial village site named Saoko (158 m above sea level), which lies near Saoko stream on the north-western side of Mt Reaumur, was identified over an hour's walk inland of Poin Kiau on the north coast of the island (Figures 6.2-6.3). At this area, two rim sherds (LI-1 and LI-3) were collected from the surface (Table 6.1), although many more were observed and left undisturbed on site. Many of these artefacts had been turned up through recent gardening activities and digging for house construction. Four pieces of obsidian were also collected: one from Poin Kiau and three from Saoko village. At another location, Matafum on the west coast, wave action had severely affected in situ and surface deposits. Only two pottery sherds were surface collected from this area (LI-4 and LI-5); however, another (LI-2) was given to Mary Mennis at the haus win by a local villager who had previously collected it nearby. Numerous non-obsidian lithic artefacts were also found at Matafum.

\section{Ceramic artefacts}

Five pottery sherds were collected from surface sites. This included two rim sherds from the inland village, and one rim, one decorated body sherd and one plain body sherd from Matafum on the coast. The sherds, which were first examined macroscopically to describe form and manufacturing technique, are as follows:

LI-1 (Figure 6.4a): A thick $(17.88 \mathrm{~mm}$ ) symmetrical everted rim fragment. The rim profile is gradually convergent to a round lip. The sherd appears to be from a globular vessel with a large orifice diameter of $220 \mathrm{~mm}$. There is no surface finish, evidence of forming technique or decoration. This rim form is not previously reported from Arop/Long Island, although it is similar to Profile 3 rim forms described by Egloff and Specht (1982: Figure 4.3). This rim form does not appear to be recent or Ancestral Madang, Type X or Sio.

LI-2 (Figure 6.4b): A thin $(6.48 \mathrm{~mm})$, flaring and everted rim fragment. From the neck, the rim profile is gradually convergent to a round lip with internal lip notching, probably produced using a thin wooden tool. The sherd appears to be from a globular vessel with an orifice diameter of $200 \mathrm{~mm}$. A purple-red slip has been applied to both the internal and external surfaces. This rim form has not previously been reported on Arop/Long but is identical to Lapita Class 1 rims reported by Lilley (2002: Figure 4a) from the KLK site on Tuam Island in the Siassi group.

LI-3 (Figure 6.4c): A 9.29-mm-thick direct rim fragment. The rim profile is abruptly divergent along a slightly convex rim course, finishing in a flat, round-edged lip form. It is unclear what the vessel form was, but the orifice diameter is similar to LI-1, and LI-2, being $210 \mathrm{~mm}$. Purple slip has been applied to both the external and internal surfaces. This rim form is most similar to Type X Class 1 rims reported by Lilley (1988b; cf. Specht et al. 2006: Figure 4a). Similar rims have been reported on Arop/Long by Egloff and Specht (1982: Figure 4.5). The rim could also be Ancestral Madang (cf. Lilley 1986: Figure 6.28) but is definitely not of the recent (last 500 years) or modern Madang styles (Gaffney et al. 2017). LI-4 and LI-5 are too fragmentary to assign definitive stylistic/technical groupings; however, the incised decorations on LI-4 are consistent with recent Madang-style pottery (see Egloff 1975; Gaffney et al. 2018). 


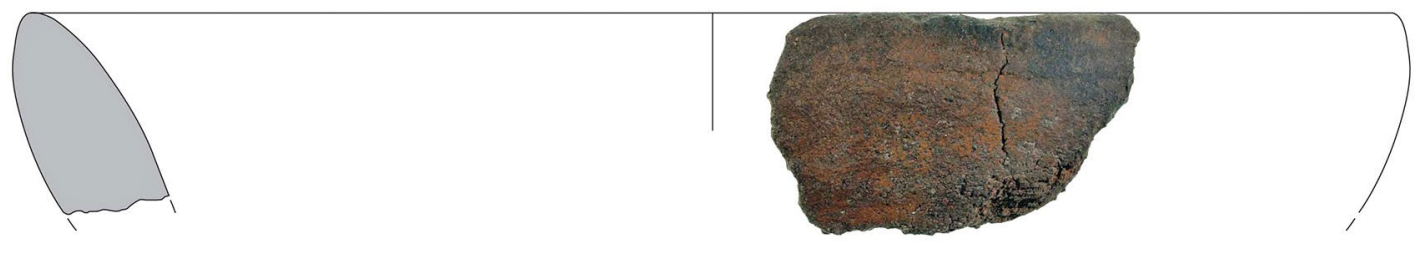

a) Rim sherd, LI-1

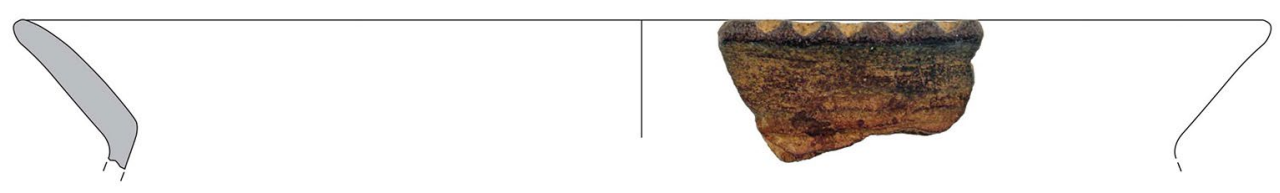

b) Rim sherd, LI-2

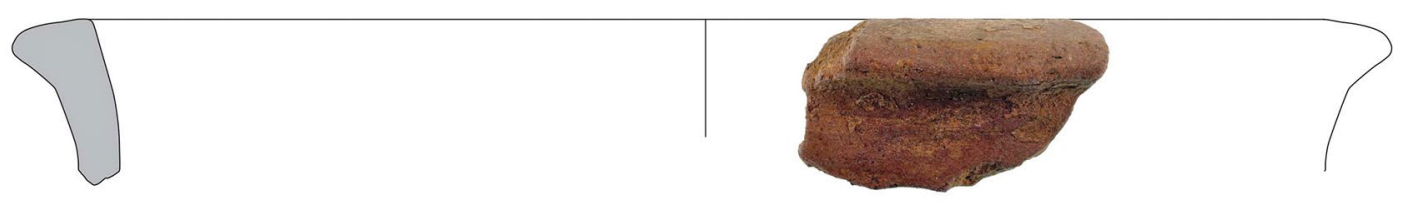

c) Rim sherd, LI-3

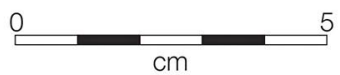

Figure 6.4. Three rim sherds surface collected from Arop/Long: (A) LI-1; (B) LI-2; and (C) LI-3.

Source: Authors' illustration.

A macroscopic (40x) inspection of the sherd fabrics indicated that rim sherd LI-1 comprises a red clay and LI-2, LI-3, LI-4 and LI-5 comprise a similar yellow clay, fired under complete oxidisation with black non-plastic inclusions. LI-3 also contains red grains that could be grog. A further examination of the non-plastic mineral inclusions in samples LI-1, LI-2 and LI-3 was completed to investigate the raw material procurement technology used to produce these pots, and to estimate possible areas of manufacture. This analysis used a Zeiss Sigma Field Emission Gun Scanning Electron Microscope (FEG SEM) with an XMax20 Silicon Drift Energy Dispersive X-ray (EDX) detector at the University of Otago to chemically distinguish different mineral grains in a single electron micrograph of the cross-sectioned sherd. This found that all samples were manually tempered with the same or very similar volcanically derived beach sand, predominantly comprised of plagioclase feldspar (anorthite), with clinopyroxene (augite), amphibole (cummingtonite) and spinels (magnetite) (Table 6.2; Figure 6.5). Small igneous rock fragments were also present, some containing augite and spinel grains. Very small $(<50 \mu \mathrm{m})$ quartz grains were observed in LI-2 and LI-3 and are probably natural inclusions in the clay. LI-1 did not include quartz, but numerous small feldspathic grains seem to naturally occur in the clay, which is more friable than LI-2 and LI-3. 
Table 6.2. Mineral inclusions identified by SEM in three Arop/Long Island rim sherds.

\begin{tabular}{|c|c|c|c|c|c|c|c|c|c|c|c|c|}
\hline & \multicolumn{2}{|c|}{ Plagioclase } & \multicolumn{2}{|c|}{ Clinopyroxene } & \multicolumn{2}{|c|}{ Amphibole } & \multicolumn{2}{|c|}{ Spinel } & \multicolumn{2}{|c|}{ Quartz } & \multicolumn{2}{|c|}{ Rock } \\
\hline & \multicolumn{2}{|c|}{ Anorthite } & \multicolumn{2}{|c|}{ Augite } & \multicolumn{2}{|c|}{ Cummingtonite } & \multicolumn{2}{|c|}{ Magnetite } & \multicolumn{2}{|c|}{-} & \multicolumn{2}{|c|}{ - } \\
\hline Sherd & $n *$ & $\mu \mathrm{m}$ & $n *$ & $\mu \mathrm{m}$ & $n *$ & $\mu \mathrm{m}$ & $n *$ & $\mu \mathrm{m}$ & $n *$ & $\mu \mathrm{m}$ & $n *$ & $\mu \mathrm{m}$ \\
\hline LI-1 & 4 & $<100-413$ & 14 & $<100-446$ & 5 & $<100-201$ & 2 & $<100-247$ & - & - & 4 & $168-253$ \\
\hline LI-2 & 18 & $<100-331$ & 7 & $<100-321$ & 6 & $<100-203$ & 5 & $<100-127$ & $Y$ & $<50$ & 6 & $161-446$ \\
\hline LI-3 & 12 & $<100-529$ & 2 & $<100->2000$ & 1 & 231 & 4 & $160-319$ & $Y$ & $<40$ & - & - \\
\hline
\end{tabular}

"number of grains $>100 \mu \mathrm{m}$

Source: Authors' data.

LI1

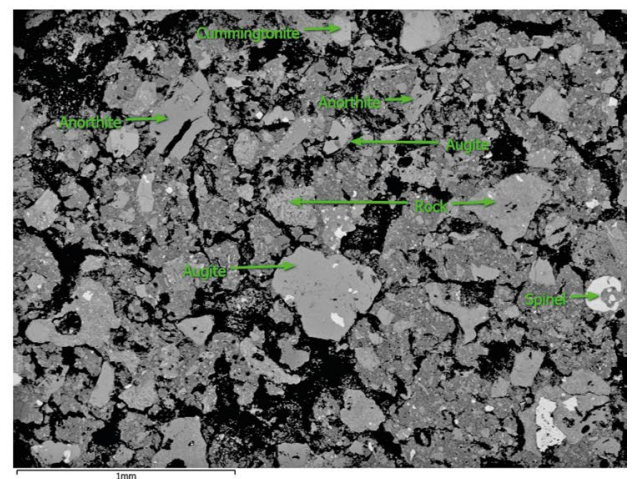

LI2

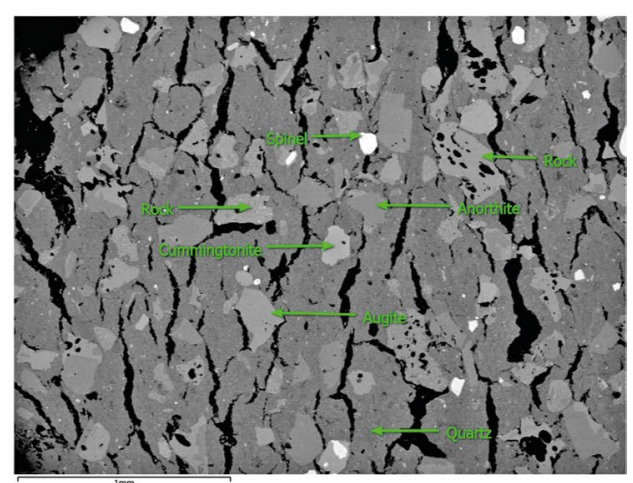

LI3

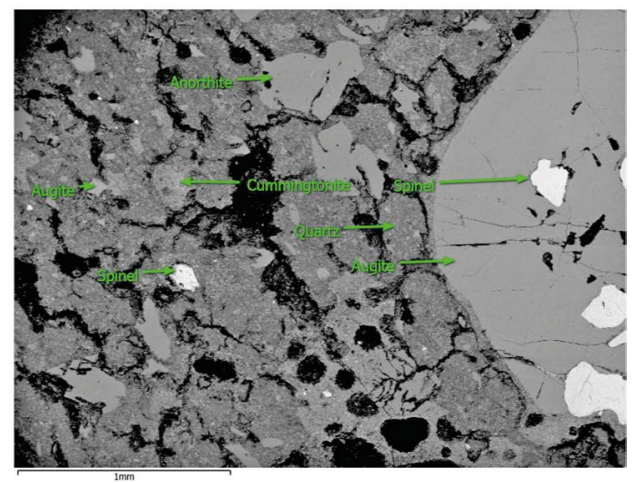

Figure 6.5. Micrographs showing mineral inclusions from Arop/Long Island rim sherds. Source: Authors' illustration.
Plagioclase, clinopyroxene, magnetite and volcanilithics are characteristic of local basalts and low-silica andesites in the Schouten Arc (comprising the Vitiaz Strait and western tip of New Britain) (Johnson et al. 1972), whereas amphibole is typically absent from these rocks (Dickinson 2006:55). These same tempers with minor amphibole do not preclude an origin in south-west New Britain, however (see Dickinson 2006:55); the Pulie river mouth source, for instance, has an almost identical range of minerals (Summerhayes 2000:170). The Arop/Long tempers are also similar to river mouth sands from north New Britain, near Garua Wharf, which contain plagioclase, pyroxene and amphibole (Summerhayes 2000:168). These pyroxenes, however, are usually a combination of both clinopyroxene and orthopyroxene. The inclusion of quartz in LI-2 and LI-3 clays suggests a probable continental source for the clay (New Guinea or New Britain). 


\section{Stone artefacts}

Nineteen stone artefacts were collected from Arop/Long, including four pieces of obsidian. The 15 non-obsidian artefacts are all made from the same stone, a low-grade volcanic rock, which is likely to be local to Arop/Long given its large size, predominance of cortex and the poor quality of the material. A geological survey map of Arop/Long suggests the island is replete with such stone, particularly tholeiitic basalt and low-silica andesite (Robinson et al. 1974). The majority of these artefacts were found at Matafum and are suggestive of on-site primary flaking activities due to the presence of large cortical cores and a lack of use wear or retouch. Higher quality obsidian raw material may have been imported to supplement the poorer quality and more brittle volcanic stone. Two of the obsidian artefacts are small retouched flakes (LI-6, LI-7), while another flake (LI-8) shows evidence of usewear. LI-9 is a small core, bifacially flaked from one striking platform. None of the obsidian artefacts show signs of cortex.

A geochemical analysis of the obsidian was conducted to distinguish the original source of procurement. All four obsidian artefacts were analysed by portable X-ray fluorescence (pXRF), using a Bruker Tracer III-SD pXRF at the University of Otago. The machine was optimised to identify mid- $\mathrm{Z}$ trace elements ( $\mathrm{Mn}, \mathrm{Fe}, \mathrm{Zn}, \mathrm{Th}, \mathrm{Rb}, \mathrm{Sr}, \mathrm{Y}, \mathrm{Zr}, \mathrm{Nb}$ ) with green filter settings $(40 \mathrm{kV}$ per channel, filament $\mathrm{ADC}=30 \mu \mathrm{A}$, filter $=12 \mathrm{milAl}+1 \mathrm{milTi}+6 \mathrm{milCu}$, runtime $=300$ seconds). The raw data were calibrated to parts per million (PPM) using both the machine-specific quantification protocols for the Bruker Tracer III-SD \#T3S2521, based on 40 known obsidian standards, and a secondary linear transform based on 12 international geological standards. A basalt standard (BHVO-2) was run at the beginning and end of the session as a quality control.

Table 6.3. Chemical concentrations of obsidian (PPM) data measured by pXRF, showing values for four Arop/Long Island obsidian artefacts.

\begin{tabular}{|c|c|c|c|c|c|c|c|c|c|}
\hline & $\mathrm{Mn}$ & $\mathrm{Fe}$ & Zn & Th & $\mathrm{Rb}$ & $\mathrm{Sr}$ & $Y$ & $\mathrm{Zr}$ & $\mathrm{Nb}$ \\
\hline \multicolumn{10}{|c|}{ Arop/Long Island artefacts } \\
\hline LI-6 & 480 & 4007 & 45 & 2 & 50 & 266 & 23 & 139 & 4 \\
\hline LI-7 & 494 & 4312 & 49 & 1 & 52 & 205 & 23 & 149 & 3 \\
\hline LI-8 & 562 & 6114 & 75 & 2 & 62 & 245 & 26 & 165 & 4 \\
\hline LI-9 & 450 & 4353 & 60 & 2 & 51 & 196 & 22 & 143 & 4 \\
\hline \multicolumn{10}{|c|}{ Geological standard BHV0_2 } \\
\hline USGS recommended & 1290 & - & - & - & - & 389 & 26 & 172 & - \\
\hline Mean recorded & 1273 & 83773 & 175 & 3 & 13 & 351 & 23 & 154 & 16 \\
\hline SD & 35.0 & 513.5 & 6.3 & $<0.1$ & 0.3 & 1.0 & 0.6 & 0.4 & 0.5 \\
\hline $\mathrm{CV}$ & $2.7 \%$ & $0.6 \%$ & $3.6 \%$ & $0.2 \%$ & $2.3 \%$ & $0.2 \%$ & $2.4 \%$ & $0.2 \%$ & $2.9 \%$ \\
\hline
\end{tabular}

The geological standard used to ensure accurate calibration is tabulated below, showing mean (of 2 runs), standard deviation and coefficient of variance, which expresses dispersion of data as a percentage.

Source: Authors' data.

The archaeological material was then statistically compared to geological reference samples from all known obsidian sources in the New Guinea area. A bivariate plot of $\mathrm{Rb} / \mathrm{Sr}$ and $\mathrm{Y} / \mathrm{Zr}$ (Figure 6.6) based on the PPM data shows that all of the Arop/Long samples plot closely to the Kutau reference source in West New Britain. The elements $\mathrm{Rb}, \mathrm{Sr}, \mathrm{Y}$ and $\mathrm{Zr}$ are important for distinguishing this source, while others account for less variation. 


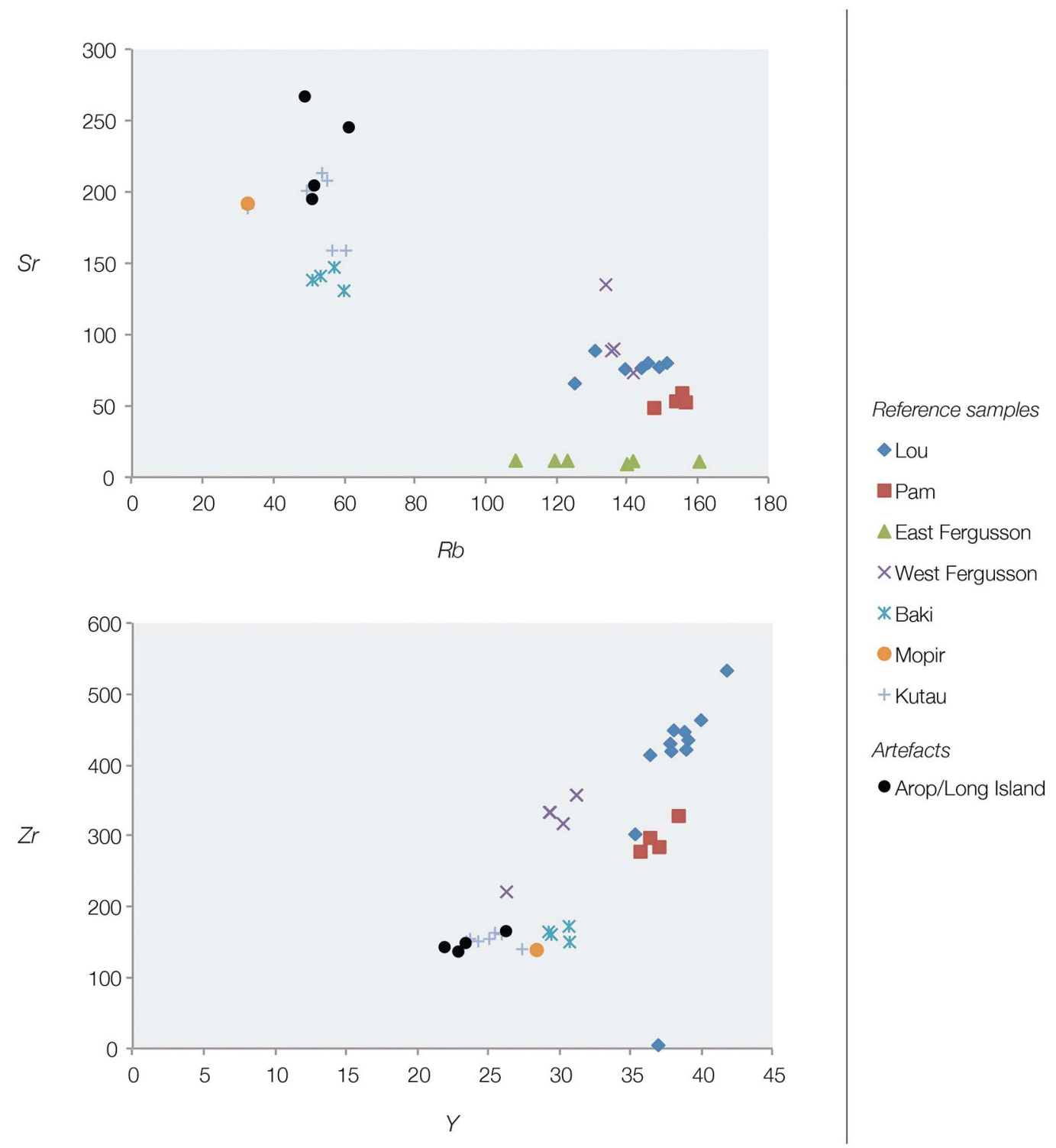

Figure 6.6. Bivariate plots of $\mathrm{Sr} / \mathrm{Rb}$ and $\mathrm{Zr} / \mathrm{Y}$.

Note that the East Fergusson source is excluded from Zr/Y plot as it condensed the other source data.

Source: Authors' data.

\section{Discussion}

The artefacts featured in this chapter are few in number but provide clues to occupation on Arop/ Long, prior to the c. $290 \mathrm{BP}$ eruption. The pot rim LI-2 presented above is identical to those found on Siassi and from West New Britain Lapita assemblages from the Arawe Islands region and the north coast on Garua Island, which are normally associated with a globular vessel Type VI as defined by Summerhayes (2000). Plainware vessels make up nearly half of all vessels from the Arawe Lapita assemblage and over 90 per cent of the Siassi sherds (Lilley 2002; Summerhayes 2000:152). These plain vessels formed the utilitarian component of Lapita ceramic traditions, probably serving a different function to more ornately decorated forms. 
Lilley (2002) describes for the Vitiaz Strait a 'fleeting Lapita presence in Siassi around 2700 cal. BP'. This is followed by a hiatus in ceramic production in the Vitiaz - West New Britain region until around 1700 years ago with the presence of Type Y pottery followed by Type X, Ancestral Madang and Sio wares. The rim LI-3 is not associated with plainware Lapita and is similar to the later Type $\mathrm{X}$ ware, which is found on the Huon Peninsula, Vitiaz Strait, and assemblages from the south-west coast of New Britain. This tradition is dated by Lilley and Specht to between 1000-600 years ago (Lilley and Specht 2007; Specht et al. 2006), although it could be a few hundred years earlier given that Summerhayes dated Type X pottery to 1560 930 cal. BP (1300 BP, ANU11192) at FOH site, squares D, E and F, at Adwe (Summerhayes 2000). The rim sherd LI-3 is not out of place here and was likely traded into Arop/Long within the last 1000 years. LI-1 is less definitively ascribable to a specific potting tradition. It does not appear to belong to any of the recent production centres in north-east New Guinea and cannot be definitely assigned to Lapita.

It is important that, although one of the rim forms described from Arop/Long correlates with Lapita and another with Type X, the mineral tempers are nearly identical-the only disparity being the slight difference in proportion of plagioclase, pyroxene and amphibole. This is suggestive of similar manufacturing locations. The two sherds (one Lapita form and the Type $\mathrm{X}$ form) contain quartz, implying the clay was quarried from a continental source (New Britain or New Guinea), while the manual tempers being only volcanically derived grains come from a beach or river mouth. Many of these minerals are found throughout the Vitiaz Strait - West New Britain area and these areal similarities make provenience studies difficult.

Type X sherds are characteristically problematic to source mineralogically as they are grogtempered, and non-plastic inclusions are usually absent (Specht et al. 2006). The Type X sherd examined here (LI-3) contains terrigenous minerals; possible grog was only identified macroscopically (i.e. not under the SEM). However, this is within the range of tempers identified in Type X from the mainland and matches samples KCR-3 from Sialum and KBQ 28-3 from Sio, which dominantly have augite and plagioclase inclusions with minor amphibole, Fe-oxides and rock fragments. These sherds are dissimilar to beach sands from the east Huon (Kulabi Beach), which are typically ferruginous. For this rare terrigenous Type X, Dickinson (in Specht et al. 2006) notes that 'derivation from the Neogene volcanic chain of the Schouten Arc cannot be ruled out on geological grounds'. Schouten Arc tempers derive from the dormant segment of the active Schouten Island Arc, which stretches from the Schouten Group off the Sepik coast down to the Arawe Islands in West New Britain. These tempers are primarily composed of pyroxenes, rare orthopyroxenes and very rare amphiboles (Dickinson 2006:55).

The significant presence of plagioclase, clinopyroxene and amphibole in LI-1, LI-2 and LI-3 allows us to hazard a working interpretation that the most likely derivation is in the Schouten Arc. Perhaps the most likely source, for LI-1 and LI-2 at least, is the south-west coast of New Britain. The Arop/Long sherd tempers are also very similar or identical to several Lapita sherds from excavated contexts in New Britain: sherd \#377 from Apugi, \#6409 from Adwe, \#3712 from Apalo and \#FA01 from Garua Island (Summerhayes 2000:171, 173, 176-177). In relation to the Siassi Lapita, the Arop/Long sherds contain similar mineral tempers (plagioclase, pyroxene, quartz, volcanic rock) but their clays are not characteristically shelly like many of those from Siassi (Lilley 2002:85). A single sherd (11/1) examined by Alan Watchman, however, does contain only pyroxene, feldspar and volcanic rock but no shell, and is the closest, mineralogically, to the Arop/ Long finds (Lilley 1986:515).

Lilley (2002) notes that some of the Siassi Type Y rims are almost identical to his Lapita Class 1 rims but characteristically contain significant amounts of amphibole, unlike the Siassi Lapita. It cannot, at present, be discounted that LI-2 in fact represents Type Y (see also Post-Lapita 
forms in Cath-Garling 2017: Figure 6.24). More definite conclusions await a larger excavated sample of Lapita/Type Y from the study area. The presence of obsidian on Arop/Long derived from Kutau is not unexpected, as Talasea obsidian (Kutau/Bao) was the main source exported to the east and west (Summerhayes 2007b) and a single piece of obsidian collected by Hughes from JCB on Arop/Long has previously been sourced to Talasea (Bird et al. 1981). Kutau obsidian has also been found from mid-Holocene contexts in mainland New Guinea. Examples include pieces found at the Eastern Highlands site of Kafiavana in contexts dated to 4500 BP (White 1972), and stemmed tools found in the Sepik-Ramu region along the north coast (Swadling and Hide 2005:307). These distinctive forms are found in New Britain from about 6000 to 3500 years ago (Araho et al. 2002). It is important to state that the Arop/Long obsidian could be Lapita-age or it could be as recent as the late 1800s AD. These results do, however, support existing interpretations that there were (perhaps strong) trade connections from New Britain to New Guinea across the Vitiaz Strait in the late Holocene. With Type X and Madang pottery originating from mainland New Guinea ending up in West New Britain, and Lapita plainware perhaps from the south-west coast of New Britain found on Arop/Long Island, we might expect movement of obsidian across the Vitiaz and Dampier Straits.

From an archaeological perspective, we can argue that over the last 1000 years there have been sporadic interactions between New Britain and New Guinea. During Lapita times there is tentative evidence for interaction between New Britain and the Vitiaz Strait, perhaps also extending to the mainland. But what was the nature of that interaction? At present, our interpretations are biased by knowledge of the exchange networks recorded in the late nineteenth and twentieth centuries. In the ethnographic period, Harding (1967) recorded the role that the Siassi played in the distribution of goods from New Britain and mainland New Guinea. How far back in time the Siassi dominated this role is unknown. Current narratives have suggested that many of the major ethnographically observed trading groups remain the same over time (see Lilley's 1988a model for example). In the past, however, Arop/Long Islanders could have played a more important role in the distribution of goods than recorded ethnographically.

The major volcanic eruption of c. 290 BP would certainly have disrupted trade and exchange configurations in the Strait. Further back in time, the role played by the people of Arop/Long Island is unknown, although hints can be found from people along the Madang coast. The pottery-producing people from Bilbil near Madang thought that obsidian originated from Arop/ Long Island as this was where they obtained it in the recent past (Summerhayes, unpublished data). This knowledge comes from a people with an extensive experience as traders along the north-east coast and in the Vitiaz Strait. Yet, the inhabitants of Arop/Long Island today think that the obsidian was natural to their island, telling Mennis and colleagues that it came from the ground. How far does this knowledge go back? Perhaps not far. Current local histories from Arop/Long Island (see Ball and Hughes 1982) suggest immigrants entered from Umboi and mainland New Guinea. These would have been after the apocalyptic eruption that Arop/Long Island experienced, however, which would have killed all of its inhabitants who did not flee. Indeed, some records suggest that the Siassi may have originally come from Arop/Long Island (recorded by Taylor-see Ball and Hughes 1982). Whatever the situation, Arop/Long Island's deep past is largely obscured by the devastating eruptive event of c. 290 BP.

The north-east coast is typified by such volcanic activity. A parallel case study is available from the Bel who now live near Madang. A study of oral traditions from the Madang area indicates that the distribution of pottery-making centres in the past along the north-east coast may not have been the same as today (Mennis 1980, 1981a, 1981b). These oral traditions describe the existence in the past of an island called Yomba somewhere west of Arop/Long Island, perhaps at the modern Hankow Reef (Mennis 2006b:11). The Yomba Islanders are said to have made pottery prior to 
their escape to the mainland at the time that Yomba erupted or sank-the inhabitants fleeing to the north-east coast of New Guinea and some even onto Arop/Long. Mennis (2006a) argues that the destruction of Yomba took place before the last major eruption of Arop/Long Island; her recent estimate of about 500 years ago is not too early for some of the Arop/Long Island pottery to have originated from Yomba (Egloff and Specht 1982:440).

\section{Conclusions}

This chapter has presented preliminary and tantalising evidence for Lapita pottery on Arop/ Long Island in the Vitiaz Strait. This adds to the small number of potential Lapita locations in north-east New Guinea; along with a single excavated context in the Siassi Islands (Lilley 1986), the Aitape sherd (Swadling 1988:19) and another surface find on Ali Island (Terrell and Welsch 1997:558). This has prompted us to revisit two central research themes. The first is the movement of Lapita peoples into the Vitiaz Strait. Did this dispersal occur in a generally westeast direction, using the islands as stepping stones from the north-east coast of New Guinea, or was it, perhaps more likely, an east-west movement from the Bismarcks? If the latter is the case, it may have been only the first in a series of movements into the Strait and onto the north-east coast of New Guinea. The second theme concerns interaction between New Guinea and New Britain. Could the postulated Lapita presence on Arop/Long represent a deliberate movement of traders to facilitate trade between the two landmasses? Or perhaps the finds only represent the end of the line in plainware Lapita pots being traded into existing Papuan populations? These ideas are all highly speculative at present and cannot be tested by the suggestive but extremely limited sample size reported here. Such ideas await future fieldwork in the interior of Arop/Long, and on nearby islands such as Crown, Tolokiwa and Bagabag. The Vitiaz Strait is certainly an area with a rich late Holocene history, which remains to be unravelled.

\section{Acknowledgements}

Thanks to the people of Arop/Long for their generosity and hospitality. Our deepest thanks to Sir Peter Barter and Sibona Mani of the Madang Resort and the crew of the Kalibobo Spirit for organising the expedition to Arop/Long Island. Dadok Tamsen, a leader of the Bel people, and earth scientists Russel Blong, Chris McKee and Stewart Fallon accompanied Mary Mennis during the Arop/Long trip. Stewart Fallon also provided correspondence about local geology and archaeology. Brent Pooley assisted with sample preparation, Liz Girvan facilitated use of the SEM, and Anne Ford provided her obsidian calibration for the University of Otago pXRF. We thank two anonymous reviewers for helpful feedback. Funding for the trip was provided by the Melanesian Foundation, a University of Otago Research Grant awarded to Glenn R. Summerhayes, and Sir Peter Barter. Particular thanks to Georgie Kapiu from the National Research Institute of Papua New Guinea. Finally, a special tenkyu tumas to the late Herman Mandui who accompanied us to Madang to help facilitate research. All research was carried out in collaboration with the National Museum and Art Gallery of Papua New Guinea, the University of Papua New Guinea and the National Research Institute of Papua New Guinea. All figures and tables were produced by the authors unless otherwise attributed. 


\section{References}

Araho, N., R. Torrence and J.P. White 2002. Valuable and useful: Mid-Holocene stemmed obsidian artefacts from West New Britain, Papua New Guinea. Proceedings of the Prehistoric Society 68:61-81. doi.org/10.1017/S0079497X00001444.

Ball, E.E. and I.M. Hughes 1982. Long Island, Papua New Guinea: People, resources and culture. Records of the Australian Museum 34(10):463-525. doi.org/10.3853/j.0067-1975.34.1982.292.

Bellwood, P. 1998. Human dispersals and colonizations in prehistory: The Southeast Asian data and their implications. In K. Omoto and P.V. Tobias (eds), The origins and past of modern humans: Towards reconciliation, pp. 188-205. World Scientific, Singapore.

Bellwood, P. 2011. The checkered prehistory of rice movement southwards as a domesticated cerealFrom the Yangzi to the Equator. Rice 4:93-103. doi.org/10.1007/s12284-011-9068-9.

Bellwood, P. and E. Dizon 2008. Out of Taiwan, via the Batanes Islands, and onwards to Western Polynesia. In A. Sanches-Mazas, R. Blench, M.D. Ross, I. Peiros and M. Lin (eds), Past human migrations in East Asia: Matching archaeology, linguistics and genetics, pp. 23-39. Routledge, London and New York. doi.org/10.4324/9780203926789.

Bird, J.R., W.R. Ambrose, L.H. Russell and M.D. Scott 1981. Characterisation of Melanesian obsidian sources and artefacts using the Proton Induced Gamma-Ray Emission (PIGME) technique. Australian Nuclear Science and Technology Organisation, Lucas Heights.

Blong, R.J. 1982. The time of darkness: Local legends and volcanic reality in Papua New Guinea. Australian National University Press, Canberra.

Blust, R. 2009. The Austronesian languages. Pacific Linguistics 602. RSPAS, The Australian National University, Canberra.

Carson, M.T., H.-C. Hung, G.R. Summerhayes and P. Bellwood 2013. The pottery trail from Southeast Asia to Remote Oceania. The Journal of Island and Coastal Archaeology 8(1):17-36. doi.org/10.1080/ 15564894.2012.726941.

Cath-Garling, S. 2017. Evolutions or revolutions? Interaction and transformation at the 'transition' in Island Melanesia. University of Otago Studies in Archaeology 27. University of Otago, Dunedin.

Chang, C.S., H.L. Liu, X. Moncada, A. Seelenfreund, D. Seelenfreund and K.F. Chung 2015. A holistic picture of Austronesian migrations revealed by phylogeography of Pacific paper mulberry. Proceedings of the National Academy of Sciences 112(44):13537-13542. doi.org/10.1073/pnas.1503205112.

Dickinson, W.R. 2006. Temper sands in prehistoric Oceanian pottery: Geotectonics, sedimentology, petrography, provenance. Geological Society of America, Special Paper 406. Geological Society of America, Boulder, Colorado. doi.org/10.1130/2006.2406.

Egloff, B.J. 1975. Archaeological investigations in the coastal Madang area and on Eloaue Island of the St. Matthias Group. Records of the Papua New Guinea Public Museum and Art Gallery 5:15-31.

Egloff, B.J. and J. Specht 1982. Long Island, Papua New Guinea: Aspects of the prehistory. Records of the Australian Museum 34(8):427-446. doi.org/10.3853/j.0067-1975.34.1982.290.

Gaffney, D., G.R. Summerhayes, A. Ford, J.M. Scott, T. Denham, J. Field and W.R. Dickinson 2015. Earliest pottery on New Guinea mainland reveals Austronesian influences in highland environments 3000 years ago. PLOS One 10(9):e0134497. doi.org/10.1371/journal.pone.0134497. 
Gaffney, D., G.R. Summerhayes, M. Mennis, T. Beni, A. Cook, J. Field, G. Jacobsen, F. Allen, H. Buckley and H. Mandui 2017. Archaeological investigations into the origins of Bel trading groups around the Madang coast, northeast New Guinea. Journal of Island and Coastal Archaeology 13:(4):501-530. doi.org/10.1080/15564894.2017.1315349.

Gray, R.D., A.J. Drummond and S.J. Greenhill 2009. Language phylogenies reveal expansion pulses and pauses in Pacific settlement. Science 323(5913):479-483. doi.org/10.1126/science.1166858.

Greenhill, S.J., A.J. Drummond and R.D Gray 2010. How accurate and robust are the phylogenetic estimates of Austronesian language relationships? PLOS One 5(3):e9573. doi.org/10.1371/journal. pone.0009573.

Haberle, S.G. 1998. Dating the evidence for agricultural change in the highlands of New Guinea: The last 2000 years. Australian Archaeology 47:1-19. doi.org/10.1080/03122417.1998.11681610.

Harding, T. 1967. Voyagers of the Vitiaz Strait: A study of a New Guinea trade system. Washington University Press, Seattle, Washington.

Hung, H.-C. 2008. Migration and cultural interaction in Southern Coastal China, Taiwan and the Northern Philippines, 3000 BC to AD 100: The early history of the Austronesian-speaking populations. Unpublished $\mathrm{PhD}$ thesis, The Australian National University, Canberra.

Johnson, R.W. 2013. Fire Mountains of the Islands: A history of volcanic eruptions and disaster management in Papua New Guinea and the Solomon Islands. ANU E Press, Canberra. doi.org/10.22459/fmi.12.2013.

Johnson, R.W., G.A.M. Taylor, R.A Davies and G.W. D’Addario 1972. Geology and petrology of Quaternary volcanic islands off the North Coast of New Guinea. Bureau of Mineral Resources, Canberra.

Kirch, P. 2000. On the road of the winds: An archaeological history of the Pacific Islands before European contact. University of California Press, Berkeley.

Lilley, I. 1986. Prehistoric exchange in the Vitiaz Strait, Papua New Guinea. Unpublished PhD thesis, The Australian National University, Canberra.

Lilley, I. 1988a. Prehistoric exchange across the Vitiaz Strait, Papua New Guinea. Current Anthropology 29:513-516. doi.org/10.1086/203669.

Lilley, I. 1988b. Type X: Description and discussion of a prehistoric ceramic ware from north eastern Papua New Guinea. Bulletin of the Indo-Pacific Prehistory Association 8:90-100. doi.org/10.7152/ bippa.v8i0.11270.

Lilley, I. 1991. Lapita and Post-Lapita developments in the Vitiaz Straits-West New Britain Area. Bulletin of the Indo-Pacific Prehistory Association 11:313-322. doi.org/10.7152/bippa.v11i0.11395.

Lilley I. 1999. Too good to be true? Post-Lapita scenarios for language and archaeology in West New Britain-North New Guinea. Bulletin of the Indo-Pacific Prehistory Association 18:25-34. doi.org/ 10.7152/bippa.v18i0.11696.

Lilley I. 2000. Migration and ethnicity in the evolution of Lapita and Post-Lapita maritime societies in northwest Melanesia. In S. O'Connor and P. Veth (eds), East of Wallace's Line: Studies of past and present maritime cultures of the Indo-Pacific region, pp. 177-195. Modern Quaternary Research in Southeast Asia 16. A.A. Balkema, Rotterdam.

Lilley, I. 2002. Lapita and Type Y pottery in the KLK site, Siassi, Papua New Guinea. In S. Bedford, C. Sand and D. Burley (eds), Fifty years in the field: Essays in honour and celebration of Richard Shutler Jr's archaeological career, pp. 79-90. New Zealand Archaeological Association Monograph 25.

New Zealand Archaeological Association, Auckland. 
Lilley, I. 2004. Trade and culture history across the Vitiaz Strait, Papua New Guinea: The emerging Post Lapita coastal sequence. Records of the Australian Museum, Supplement 29:89-96. doi.org/10.3853/ j.0812-7387.29.2004.1405.

Lilley, I. 2007. The evolution of Sio pottery: Evidence from three sites in northeastern Papua New Guinea. In J. Specht (ed.), Archaeological studies of the middle and late Holocene, Papua New Guinea, pp. 227244. Technical Reports of the Australian Museum 20. Australian Museum, Sydney. doi.org/10.3853/ j.1835-4211.20.2007.1479.

Lilley, I. and J. Specht 2007. Revised dating of Type X pottery, Morobe Province. In J. Specht and V. Attenbrow (eds), Archaeological studies of the middle and late Holocene, Papua New Guinea, Part VI, pp. 217-226. Technical Reports of the Australian Museum 20. Australian Museum, Sydney. doi.org/ 10.3853/j.1835-4211.20.2007.1478.

McNiven, I.J., B. David, T. Richards, K. Aplin, B. Asmussen, J. Mialanes, M. Leavesley, P. Faulkner and S. Ulm 2011. New direction in human colonisation of the Pacific: Lapita settlement of south coast New Guinea. Australian Archaeology 72:1-6. doi.org/10.1080/03122417.2011.11690525.

Mennis, M.R. 1980. Oral testimonies from Coastal Madang, Part 1. Oral History 8(10). Institute of Papua New Guinea Studies, Port Moresby.

Mennis, M.R. 1981a. Oral testimonies from Coastal Madang, Part 2. Oral History 9(1). Institute of Papua New Guinea Studies, Port Moresby.

Mennis, M.R. 1981b. Oral testimonies from Coastal Madang, Part 3. Oral History 9(2). Institute of Papua New Guinea Studies, Port Moresby.

Mennis, M. 2006a. A potted history of Madang: Traditional culture and change on the North Coast of Papua New Guinea. Lalong Enterprises, Aspley.

Mennis, M. 2006b. Yomba Island, Hankow Reef: Atlantis of the South Pacific, fact or fiction? Unpublished paper. Lalong Enterprises, Aspley.

Moeder, F. 1972. Franz Moeder written in 1972 about Long Island. Unpublished interview transcript, Brisbane (on file with Mary Mennis at Riesling St, Carseldine, Brisbane, Queensland, 4034, Australia).

Negishi, Y. and R. Ono 2009. Kasasinabwana shell midden: The prehistoric ceramic sequence of Wari Island in the Massim, eastern Papua New Guinea. People and Culture in Oceania 25:23-52.

Oppenheimer, S. 2004. The express train from Taiwan to Polynesia: On the congruency of proxy lines of evidence. World Archaeology 36:591-600. doi.org/10.1080/0043824042000303773.

Pétrequin, A.M. and P. Pétrequin 1999. La poterie en Nouvelle-Guinée: savoir-faire et transmission des techniques. Journal de la Société des Océanistes 108(1):71-101. doi.org/10.3406/jso.1999.2080.

Reimer, P.J., E. Bard, A. Bayliss, J.W. Beck, P.G. Blackwell, C. Bronk Ramsey, C.E. Buck, H. Cheng, R.L. Edwards, M. Friedrich, P.M. Grootes, T.P. Guilderson, H. Haflidason, I. Hajdas, C. Hatte, T.J. Heaton, D.L. Hoffmann, A.G. Hogg, K.A. Hughen, K.F. Kaiser, B. Kromer, S.W. Manning, M. Niu, R.W. Reimer, D.A. Richards, E.M. Scott, J.R. Southon, R.A. Staff, C.S.M. Turney and J. van der Plicht 2013. IntCal13 and Marine13 radiocarbon age calibration curves 0-50,000 years cal. BP. Radiocarbon 55:1869-1887. doi.org/10.2458/azu_js_rc.55.16947.

Robinson, G.P., A.L. Jaques and C.M. Brown 1974. Explanatory notes on the Madang Geological Map. Geological Survey of Papua New Guinea, Port Moresby.

Ross, M. 1988. Proto-Oceanic and the Austronesian languages of Western Melanesia. Pacific Linguistics C-98. RSPacS, The Australian National University, Canberra. 
Sheppard, P.J., S. Chiu and R. Walter 2015. Re-dating Lapita movement into Remote Oceania. Journal of Pacific Archaeology 6(1):26-36.

Skelly, R., B. David, F. Petchey and M. Leavesley 2014. Tracking ancient beach-lines inland: 2600-yearold dentate-stamped ceramics at Hopo, Vailala River region, Papua New Guinea. Antiquity 88(340):470-487. doi.org/10.1017/S0003598X00101127.

Skoglund, P., C. Posth, K. Sirak, M. Spriggs, F. Valentin, S. Bedford, G. Clark, C. Reepmeyer, F. Petchey, D. Fernandes, Q. Fu, E. Harney, M. Lipson, S. Mallick, M. Novak, N. Rohland, K. Stewardson, S. Abdullah, M. Cox, F. Friedlaender, J. Friedlaender, T. Kivisild, G. Koki, P. Kusuma, A. Merriwether, F.-X. Ricaut, J. Wee, N. Patterson, J. Krause, R. Pinhasi and D. Reich 2016. Genomic insights into the peopling of the Southwest Pacific. Nature 538(7626):510-513 and Supplementary Information. doi.org/10.1038/nature19844.

Smithsonian Institution 2015. Global volcanism program. volcano.si.edu [accessed 31 October 2018].

Specht, J. and R. Torrence 2007a. Pottery of the Talasea Area, West New Britain Province. In J. Specht (ed.), Archaeological studies of the Middle and Late Holocene, Papua New Guinea, pp. 131-196. Technical Reports of the Australian Museum, 20. Sydney: Australian Museum.

Specht, J. and R. Torrence 2007b. Lapita all over: Land-use on the Willaumez Peninsula, Papua New Guinea. In S. Bedford, C. Sand and S.P. Connaughton (eds), Oceanic explorations: Lapita and Western Pacific settlement, pp. 71-96. Terra Australis 26. ANU E Press, Canberra. doi.org/10.22459/ TA26.2007.

Specht, J., E.E. Ball, R.J. Blong, B.J. Egloff, I.M. Hughes, C.O. McKee and C.F. Pain 1982. Long Island, Papua New Guinea: Introduction. Records of the Australian Museum 34(6):407-417. doi.org/10.3853/ j.0067-1975.34.1982.288.

Specht, J., I. Lilley and W.R. Dickinson 2006. Type X pottery, Morobe Province, Papua New Guinea: Petrography and possible Micronesian relationships. Asian Perspectives 45:24-47. doi.org/10.1353/ asi.2006.0015.

Specht, J., T. Denham, J. Goff and J.E. Terrell 2014. Deconstructing the Lapita Cultural Complex in the Bismarck Archipelago. Journal of Archaeological Research 22(2):89-140. doi.org/10.1007/s10814013-9070-4.

Summerhayes, G.R. 2000. Lapita interaction. Terra Australis 15. Department of Archaeology and Natural History and the Centre for Archaeological Research, The Australian National University, Canberra.

Summerhayes, G.R. 2007a. The rise and transformation of Lapita in the Bismarck Archipelago. In S. Chiu and C. Sand (eds), From Southeast Asia to the Pacific: Archaeological perspectives on the Austronesian expansion and the Lapita Cultural Complex, pp. 129-172. Centre for Archaeological Studies, Research Centre of Humanities and Social Sciences. Academia Sinica, Taipei.

Summerhayes, G.R. 2007b. Island Melanesian pasts: A view from Archaeology. In J. Friedlaender (ed.), Genes, language and culture history in the Southwest Pacific, pp. 10-35. Oxford University Press, New York. doi.org/10.1093/acprof:oso/9780195300307.003.0002.

Swadling, P. 1988. The Sepik-Ramu: An introduction. Papua New Guinea National Museum, Boroko.

Swadling, P. and R. Hide 2005. Changing landscape and social interaction: looking at agricultural history from a Sepik-Ramu perspective. In A. Pawley, R. Attenborough, R. Hide and J. Golson (eds), Papuan pasts: Cultural, linguistic and biological histories of Papuan-speaking peoples, pp. 289-328. Pacific Linguistics 572. RSPAS, The Australian National University, Canberra.

Terrell, J.E. 2004. The 'sleeping giant' hypothesis and New Guinea's place in the prehistory of Greater Near Oceania. World Archaeology 36(4):601-609. doi.org/10.1080/0043824042000303782. 
Terrell, J.E. and R.L. Welsch 1997. Lapita and the temporal geography of prehistory. Antiquity 71:548572. doi.org/10.1017/S0003598X0008532X.

Thornton, I.W.B. 2001. Colonization of an island volcano, Long Island, Papua New Guinea, and an emergent island, Motmot, in its caldera lake. I. General introduction. Journal of Biogeography 28:1299-1310. doi.org/10.1046/j.1365-2699.2001.00642.x.

Valentin, F., F. Détroit, M. Spriggs and S. Bedford 2016. Early Lapita skeletons from Vanuatu show Polynesian craniofacial shape: Implications for Remote Oceanic settlement and Lapita origins. Proceedings of the National Academy of Sciences 113(2):292-297. doi.org/10.1073/pnas.1516186113.

White, J.P. 1972. Ol Tumbuna: Archaeological excavations in the Eastern Central Highlands, Papua New Guinea. Terra Australis 2. Department of Prehistory, RSPacS, The Australian National University, Canberra. 
This text is taken from Debating Lapita: Distribution, Chronology, Society and Subsistence, edited by Stuart Bedford and Matthew Spriggs, published 2019 by ANU Press,

The Australian National University, Canberra, Australia.

doi.org/10.22459/TA52.2019.06 